\title{
Infeksjonsrisiko hos orienteringsløpere
}

\author{
Sammendrag \\ Bakgrunn. Forskning hos orienterings- \\ løpere er nyttig for å kartlegge infek- \\ sjonsrisikoen ved å drive fysisk aktivitet \\ i skogen. I denne oversiktsartikkelen \\ gjennomgås fire ulike infeksjonstil- \\ stander hos orienteringsløpere, og \\ effekten av iverksatte forebyggende \\ tiltak diskuteres.
}

\section{Materiale og metode. Oversikten er basert på et ikke-systematisk littera- tursøk i PubMed.}

Resultater. Innen orienteringsidretten var det tidligere en opphopning av hepatitt B-virusinfeksjon. Denne opphørte etter at permanente regler om heldekkende klær ble innført. I 1980årene var det økt forekomst av plutselig død hos unge svenske orienteringsløpere. Bartonellainfeksjon er siden foreslått som mulig utløsende årsak. Ingen slik opphopning er registrert etter at det i 1992 kom spesifikke råd vedrørende trening og konkurranse. Det er ikke dokumentert at borreliainfeksjon eller skogflåttencefalitt forekommer hyppigere hos orienteringsløpere enn hos andre, men kun to eldre studier foreligger.

Fortolkning. Ut fra en generelt økende forekomst av både borreliainfeksjon og skogflåttencefalitt i Norge kan det ikke utelukkes at begge disse sykdommene i fremtiden vil bli en trussel. Helsepersonell bør fortløpende vurdere om orienteringsløpere og andre som ferdes i områder med stor utbredelse av infisert skogflått bør vaksineres mot skogflåttencefalittvirus.

\author{
Knut Hagen \\ knut.hagen@ntnu.no \\ Nasjonalt kompetansesenter for hodepine \\ Avdeling for nevrologi og klinisk nevrofysiologi \\ St. Olavs hospital \\ 7006 Trondheim \\ og \\ Institutt for nevromedisin \\ Det medisinske fakultet \\ Norges teknisk-naturvitenskapelige universitet
}

Turer i skog og mark regnes som helsefremmende. Orienteringsløpere er blant dem som er mye ute i naturen, og forskning på denne gruppen er derfor nyttig for kartlegging av mulige negative helseeffekter knyttet til aktiviteter i skogen. Selv om leddbåndsskader og hudsår er de vanligste problemene $i$ forbindelse med orienteringsløp (1), har forskningen i hovedsak vært konsentrert om potensiell infeksjonsrisiko. Innen orienteringsidretten var det tidligere - i 1960-årene - en opphopning av hepatitt B-virusinfeksjon (2), og i 1980-årene var det økt forekomst av plutselig død hos unge svenske orienteringsløpere - med mulig infeksiøs etiologi (3). I den senere tid har det vært økende interesse for betydningen av smittebærende organismer, spesielt sykdomsinfisert skogflått. Mest kjent er infeksjon med bakterien Borrelia burgdorferi (4), men flått kan også være bærer av et virus som kan gi skogflåttencefalitt (5).

I denne oversiktsartikkelen gjennomgås fire ulike infeksjonstilstander som er registrert hos orienteringsløpere. Effekten av iverksatte forebyggende tiltak diskuteres også.

\section{Materiale og metode}

Artikkelen er basert på et ikke-systematisk litteratursøk i PubMed med et skjønnsmessig utvalg av artikler basert på forfatterens egen erfaring i nevrologi og orientering.

\section{Hepatitt B-virus}

I perioden 1957-66 ble det registrert 611 svenske og over 100 norske orienteringsløpere med hepatitt B-virusinfeksjon $(2,6)$. De første svenske løperne var hjemmehørende i Göteborg. I de påfølgende år ble det rapportert om stadig nye tilfeller i midtre og sørlige deler av Sverige.

Årsak til opphopningen av hepatitt B-virusinfeksjon ble antatt å være smitte via åpne sår og rifter i huden (6). Flere mulige overføringsmåter er blitt diskutert, deriblant dårlige hygieniske forhold på samlingsplassen (bruk av felles vaskevannsfat), bad i stil- lestående vann og dårlig avløp for dusjene. Overføring av infisert blod ute i terrenget er også teoretisk mulig - ved at flere løpere river seg opp på de samme kvistene eller tornene rundt fellesposter $(2,6)$.

Det tok nærmere fem år fra de første tilfellene ble rapportert til det svenske orienteringsforbundet iverksatte tiltak. Våren 1962 ble alle planlagte løp avlyst, samtidig ble det innført en karantenetid for deltakelse i løp for sykdomsaffiserte (6). Videre ble det gitt særskilte hygieniske retningslinjer. Det kom også nye forskrifter for bekledningen - med påbud om såkalt heldekking av kroppen (unntatt hode, hals og hender). Før dette var kortbukse og kortermet trøye vanlig antrekk i løp. I Norge ble regler om heldekking innført høsten 1963 (2). Reglene vakte motstand hos de aktive, noe som er angitt som årsak til at bekledningsreglementet ble opphevet etter kort tid. Ny økning i antall orienteringsløpere med hepatitt medførte imidlertid at reglene om heldekking ble gjennomført på permanent basis i Sverige fra 1966 og i Norge fra 1967 (2, 6).

\section{Plutselig død}

I perioden mellom 1979 og 1992 døde én kvinnelig og 15 mannlige svenske eliteutøvere $\mathrm{i}$ orientering (3). I samme tidsrom ble det ikke registrert noen tilsvarende opphopning av plutselig, uventet død hos eliteutøvere $i$ andre idrettsgrener (3).

Det svenske orienteringsforbundet anbefalte i desember 1992 alle eliteutøvere å avstå fra trening og konkurranser de neste seks månedene. Det ble også formidlet råd om ikke å trene hvis man hadde symptomer på infeksjon, sørge for tilstrekkelig hvile mellom treningsøktene og å unngå åpne sår ved

\section{Hovedbudskap}

- Opphopning av hepatitt B-virusinfeksjon og plutselig, uventet død har utløst flere forebyggende tiltak i orienteringsidretten

- Etter innføring av regler om heldekkende bekledning forsvant opphopningen av hepatitt B-virusinfeksjon

- Nye, mindre strenge bekledningsregler kan på sikt endre infeksjonsrisikoen

- For orienteringsløpere er det aktuelt med vaksine mot skogflåttencefalittvirus 
alltid å bruke heldekkende bekledning i skogen. En mer liberal holdning til bruk av antibiotika ble også formidlet til både aktive og helsepersonell (7).

Samtidig ble flere ulike undersøkelser foretatt $i$ håp om å finne den bakenforliggende årsaken. Ved obduksjon ble morforlogiske forandringer i hjertet av ulik grad beskrevet hos alle de 16 døde, og hos flertallet var det forandringer forenlig med myokarditt (8). Immunologisk kartlegging utført hos 119 eliteløpere og hjerteundersøkelser utført hos 64 ga ikke ytterligere avklaring $(9,10)$. Ved spesialundersøkelser ble imidlertid bakterien Chlamydia pneumoniae påvist i hjerte og lunge hos en av de døde (3). Forhøyet antistofftiter (IgG) mot Chlamydia pneumoniae ble $\mathrm{i}$ ettertid også påvist hos fire av fem der blodprøver forelå (3).

Nyere forskning har siden antydet at infeksjon med Bartonella kunne være en mulig bakenforliggende årsak (7). Bakterien er kanskje mest kjent for å forårsake katteklorfeber (cat-scratch-disease), der Bartonella henselae overføres ved kattebitt eller kloring (11). Flere studier har vist at bakterien også smitter via skogflått og blodsugende insekter (12). Dette er blitt brukt som forklaring på hvorfor plutselig død i større grad var et fenomen hos eliteløpere $\mathrm{i}$ orientering enn hos utøvere av andre utholdenhetsidretter (7). Bakterien er ellers assosiert med hjertebetennelse hos blant annet hjemløse og narkomane (13). Bartonella-DNA er påvist hos alle de fem orienteringsløperne der autopsimateriale forelå i ettertid, i hjertet hos fire og i lungene hos den femte (7). I blodprøvene tatt i 1992-93 av 1790 svenske eliteløpere i orientering var forekomsten av forhøyet antistofftiter mot Bartonella mye høyere enn hos blodgivere (31\% versus $7 \%$ ) (14). Til sammenlikning var andelen med forhøyet antistofftiter mot Chlamydia pneumoniae noe lavere blant orienteringsløperne enn hos blodgiverne ( $53 \%$ versus $59 \%$ ) (15). I ettertid er forhøyede nivåer av antistoffer mot Bartonella påvist hos kun én av 43 danske eliteløpere (2\%) i orientering (16). Hvorfor bakterien bare er et problem for svenske orienteringsløpere, er fortsatt uavklart (16).

Det har i den senere tid vært økende interesse for infeksjoner forårsaket av Bartonella. Smitte via skogflått er spesielt viktig for orienteringsløpere. Bartonellainfisert skogflått er blitt påvist i mange land, deriblant Polen (17). Tilsvarende studier er ikke utført i Skandinavia. Det kan imidlertid nevnes at det ikke er funnet holdepunkter for bartonellainfeksjon hos norske katter (11). Og at det finnes bartonellainfisert skogflått i Danmark, blir ansett som lite sannsynlig, siden $88 \%$ av de omtalte danske orienteringsløperne var blitt bitt av skogflått det siste året (16).

\section{Borreliainfeksjon}

Det foreligger to studier der man har vurdert forekomsten av borreliainfeksjon hos orienteringsløpere. I 1986 oppgav $78 \%$ av 964

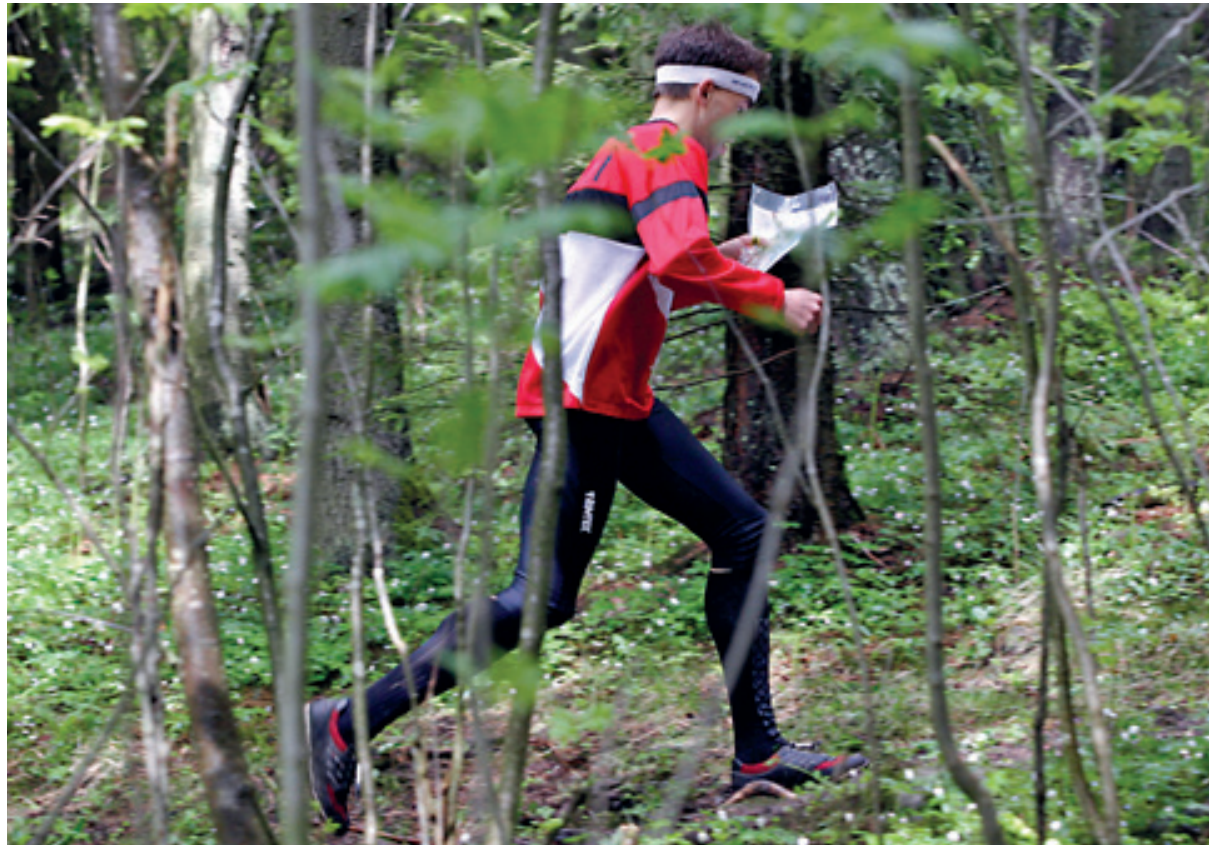

Orienteringsløper med godkjent antrekk som dekker hele kroppen unntatt hode, hals og hender, i henhold til regler innført i 1967. Illustrasjonsfoto (c) Espen Bratlie/Samfoto

sveitsiske orienteringsløpere at de en eller flere ganger tidligere var blitt bitt av skogflått. Ved blodprøver ble forhøyet antistofftiter (IgG) mot Borrelia burgdorferi påvist hos $26 \%$ (18). Kliniske symptomer forenlig med Lyme-borreliose var imidlertid mer uvanlig. I en sju års oppfølgende studie av disse sveitsiske orienteringsløperne ble det konkludert med en årlig sykdomsinsidens av Lyme-borreliose på under $1 \%$, som ikke er høyere enn insidensen i den generelle sveitsiske populasjonen $(18,19)$.

I 1990 rapporterte $53 \%$ av 362 svenske orienteringsløpere hjemmehørende i Stockholms-området om flåttbitt i løpet av det siste året (20). I blodprøver ble det påvist forhøyet antistofftiter ( $\mathrm{IgG})$ mot Borrelia burgdorferi hos 9\% (20). En tilsvarende forekomst - 9\% - ble også funnet hos 150 kontrollpersoner fra samme område (20). Tidligere gjennomgått Lyme-borreliose ble rapportert hos $6 \%$ av orienteringsløperne, og det ble konkludert med at denne sykdommen ikke var vanligere hos orienteringsløpere enn hos øvrige innbyggere i Stockholms-området (20).

I studiene fra Sveits og Sverige rapporterte flertallet av orienteringsløperne om flåttbitt, mens betydelig færre hadde forhøyede nivåer av antistoffer mot Borrelia burgdorferi. Denne forskjellen kan delvis forklares med at smitte kan forhindres dersom skogflåtten fjernes raskt (21). De færreste flåtter er infisert med Borrelia burgdorferi, for eksempel ble bakterien påvist hos under $20 \%$ av totalt 341 eksemplarer undersøkt i SørNorge sommeren 1999 (22).

\section{Skogflåttencefalitt}

I tillegg til Borrelia burgdorferi kan skogflått være infisert med blant annet skogflåttence- falittvirus (tick-borne encephalitis virus, TBEV). Det foreligger bare én studie der man har kartlagt forekomsten av skogflåttencefalitt (TBE) hos orienteringsløpere. I en svensk studie med 362 svenske orienteringsløpere hadde $1 \%$ antistoffer mot skogflåttencefalittvirus i serum, mens kun én av dem hadde gjennomgått skogflåttencefalitt. En slik lav forekomst var ikke høyere enn forekomsten i den øvrige befolkning i tilsvarende område (20). I Sverige har de fleste smittede bodd i Stockholms-området, der den gjennomsnittlige årlige insidens av skogflåttencefalitt $i$ årene 1955-93 var 3,4 per 100000 innbyggere (23).

\section{Effekt av forebyggende tiltak}

Opp gjennom årene har det svenske orienteringsforbundet både avlyst løp, innført karantenetid for syke og gitt regler for hygiene og bekledning samt kommet med praktiske råd om trening under sykdom. Det er i ettertid usikkert hva slags effekt hvert enkelt av disse forebyggende tiltak har hatt.

I ettertid fremstår særlig reglene om heldekkende klær som viktige. Sår og rifter i huden var angitt som den grunnleggende forutsetningen for opphopningen av hepatitt B-virusinfeksjon. Etter at reglene om heldekking ble innført på permanent basis, har det ikke vært registrert noen ny slik opphopning. Reglene om bekledning er også nevnt som mulig forklaring på hvorfor borreliainfeksjon og skogflåttencefalitt ikke ser ut til å forekomme hyppigere hos orienteringsløpere enn i den øvrige befolkningen.

Etter 1992 er det heller ikke blitt registrert noen opphopning av plutselig død hos orienteringsløpere i Sverige. Mulige forklaringer er at løperne i mindre grad har trent og konkurrert under pågående infeksjon samt at hel- 
sepersonell har hatt en mer liberal holdning til bruk av antibiotika for denne gruppen (7). De mange tilfellene av plutselig hjertedød hos de svenske løperne fikk stor oppmerksomhet i Norge. Det er derfor teoretisk mulig at de forebyggende rådene $\mathrm{i}$ vårt naboland har hatt en preventiv effekt også her i landet.

\section{Potensielle helsebekymringer i fremtiden}

Kunnskapen om infeksjonsrisiko hos orienteringsløpere er først og fremst basert på forskning hos svenske løpere. Tilsvarende undersøkelser om de norske foreligger ikke. Forhistorien tilsier imidlertid at det bør foregå en kontinuerlig observasjon av helsetilstanden hos orienteringsløpere også her til lands.

Til tross for at reglene om heldekking fremstår som et viktig forebyggende tiltak, har det $\mathrm{i}$ det $\mathrm{i}$ den senere tid skjedd en endring i reglementet. Det er igjen tillatt med kortermet trøye i alle typer løp. I sprintløp (som i mindre grad medfører ferdsel i terrenget) er det tillatt med kortbukser. Antrekk som ikke gir særlig beskyttelse av huden, vil innebære økt risiko for sår og rifter. Dette burde motivere ytterligere til kontinuerlig observasjon av orienteringsløpernes helsetilstand.

Det er få studier der man har vurdert forekomsten av Lyme-borreliose og skogflåttencefalitt hos denne gruppen idrettsutøvere. De som finnes, er gjort for mange år siden. Det kan således ikke utelukkes at begge disse sykdommene vil være en helsetrussel for orienteringsløpere i Norge i fremtiden. Et forventet stadig varmere klima gjør trolig at forekomsten av Lyme-borreliose og skogflåttencefalitt vil fortsette å øke (24). I Norge er Lyme-borreliose vanligst langs kysten i sør og opp til Trøndelag (4), og antallet sykdomstilfeller er tredoblet fra 1997 (112 tilfeller) til 2008 (345 tilfeller) (25). I Sverige har det på tilsvarende vis vært en tredobling av antall diagnostiserte tilfeller av skogflåttencefalitt fra 1990 (54 tilfeller) til 2007 (189 tilfeller) (26). Til sammenlikning var det i Norge ved utgangen av 2007 totalt registrert 28 skogflåttencefalittilfeller, derav 13 nye i 2007 (25). De fleste av dem som er blitt rammet har vært hjemmehørende i Agder-fylkene, spesielt har det vært mange smittede på Tromøya (25).

\section{Praktiske konsekvenser}

Forebyggene tiltak mot flåttbitt er viktig for alle som ferdes i skog og mark i områder der det er mye flått. Tildekking av bar hud og bruk av myggmidler på klærne anbefales. Etter turen bør man kontrollere at man ikke har flått på kroppen, eventuelle slike bør raskest mulig fjernes med pinsett eller neglene $(21,27)$. Antibiotika skal gis til alle med manifestasjoner av Lyme-borreliose (4).

Ved skogflåttencefalitt, derimot, kan sykdomsutviklingen i liten grad påvirkes av behandling. Forebyggende tiltak, som vaksi- nering av dem som bor i risikoområder, er derfor viktig. Nylig har Folkehelseinstituttet anbefalt vaksinering av orienteringsløpere, skogsarbeidere og fotturister som ferdes i områder med stor utbredelse av infisert skogflått (28). Til nå er det få som har fulgt dette rådet. Ifølge salgstall hentet fra reseptregisteret ble det i perioden 2005-07 i gjennomsnitt solgt under 100 vaksiner i Norge per år (29). Til sammenlikning er mer enn 200000 mennesker i Stockholms-området blitt vaksinert (24). Ut fra et lavt salgstall av vaksine i Norge kan helsepersonell trenge en påminnelse om fortløpende å vurdere om orienteringsløpere og andre som er glad i å ferdes i skog og mark trenger vaksine mot skogflåttencefalitt. Det er anbefalt til sammen tre doser. De to første gis med 1-3 måneders intervall, tredje dose gis etter 5-12 måneder (28). To doser vil gi en beskyttelse på $90 \%$, etter tre doser er beskyttelsesgraden $97 \%(28,30)$.

\section{Oppgitte interessekonflikter: Ingen}

\section{Litteratur}

1. Linko PE, Blomberg HK, Frilander HM. Orienteering competition injuries: injuries incurred in the Finnish Jukola and Venla relay competitions. Br J Sports Med 1997: 31: 205-8.

2. Vellar OD. Hepatitt hos orienteringsløpere. Tidsskr Nor legeforen 1967; 87: 1903-5.

3. Wesslén L, Påhlson C, Lindquist $O$ et al. An increase in sudden unexpected cardiac deaths among young Swedish orienteers during 1979-1992. Eur Heart J 1996; 17: 902-10.

4. Ljøstad U, Mygland $\AA$. Lyme-borreliose hos voksne. Tidsskr Nor Legeforen 2008; 128: 1175-8.

5. Skarpaas T, Sundøy A, Bruu AL et al. Skogflåttencefalitt i Norge. Tidsskr Nor Lægeforen 2002; 122: $30-2$.

6. Ringertz 0 . Serum hepatitis in Swedish trackfinders. Scan J Infect Dis 1971; 2 (suppl 2): 3-25.

7. Wesslén L, Ehrenborg C, Holmberg M et al. Subacute Bartonella infection in Swedish orienteers succumbing to sudden unexpected cardiac death or having malignant arrhythmias. Scand J Infect Dis 2001; 33: 429-38.

8. Larsson E. Wesslén L. Lindquist 0 et al. Sudden unexpected cardiac deaths among young Swedish orienteers - morphological changes in hearts and other organs. APMIS 1999; 107: 325-36.

9. Lannergård A, Fohlman J, Wesslén $L$ et al. Immune function in Swedish élite orienteers. Scan J Med Sci Sports 2001; 11: 274-9.

10. Damm S, Andersson G, Henriksen E et al. Wall motion abnormalities in male elite orienteers are aggravated by exercise. Clin Physiol 1999: 19: 121-6.

11. Bergh $K$, Bevanger L, Hanssen I et al. Low prevalence of Bartonella henselae infections in Norwegian domestic and feral cats. APMIS 2002; 110: 309-1

12. Billeter SA, Levy MG, Chomel BB et al Vector transmission of Bartonella species with emphasis on the potential for tick transmission. Med Vet Entomol 2008; 22: 1-15.

13. Chomel BB, Boulouis HJ, Maruyama S et al. Bartonella spp. in pets and effect on human health. Emerg Infect Dis 2006; 12: 389-94.

14. McGill S, Wesslén L, Hjelm E et al. Serological and epidemiological analysis of the prevalence of Bartonella spp. antibodies in Swedish elite orienteers 1992-93. Scand J Infect Dis 2001; 33: 423-28.

15. Hjelm E, Wesslén L, Gnarpe H et al. Antibodies to Chlamydia pneumoniae in young Swedish orienteers. Scand J Infect Dis 2001: 33: 589-92.

16. Schiellerup P. Dyhr T, Rolain JM et al. Low prevalence of Bartonella species in Danish elite orienteers. Scan J Infect Dis 2004; 36: 604-6.

17. Podsiadly E, Chmielewski T, Sochon E et al. Bartonella henselae in the human environment in Poland. Scand J Infect Dis 2007: 39: 956-62.
18. Fahrer $\mathrm{H}$, van der Linden SM, Sauvain MJ et al. The prevalence and incidence of clinical and asymptomatic Lyme borreliosis in a population at risk. J Infect Dis 1991: 163: 305-10.

19. Fahrer H Sauvain MJ, Zhioua E et al. Longterm survey (7 years) in a population at risk for Lyme borreliosis: what happens to the seropositive individuals? Eur J Epidemiol 1988; 14: 117-23.

20. Gustafson R, Forsgren M, Gardulf A et al. Antibody prevalence and clinical manifestations of Lyme borreliosis and tick-borne encephalitis in Swedish orienteers. Scand J Infect Dis 1993; 25: 605-11.

21. Piesman J, Mather TN, Sinsky RJ et al. Duration of tick attachment and Borrelia burgdorferi transmission. J Clin Microbiol 1987; 25: 557-8.

22. Jenkins A, Kristiansen BE, Allum AG et al. Borrelia burgdorferi sensu lato and Ehrlichia spp. in Ixodes ticks from southern Norway J Clin Microbiol 2001; 39: $3666-71$

23. Haglund M, Forsgren M, Lindh G et al. A 10-year follow-up study of tick-borne encephalitis in the Stockholm area and a review of the literature: need for a vaccination strategy. Scand J Infect Dis 1996; 28: 217-24

24. Lindgren E, Gustafson R. Tick-borne encephalitis in Sweden and climate change. Lancet 2001; 358 $16-8$

25. Folkehelseinstituttet. MSIS-statistikk. www.msis.no (31.3.2009).

26. Mantke DO, Schädler R, Niedrig M. A survey on cases of tick-borne encephalitis in European countries. Euro Surveill 2008; 13: 1-8.

27. Aavitsland P. Flåttsommer. Tidsskr Nor Legeforen 2008; 128: 1163

28. Skogflåttencefalittvaksine (TBE-vaksine). Vaksinasjonshåndboka i e-bokversjon. www.fhi.no/eway/ default.aspx?pid=233\&trg=MainLeft_6039\&MainAr ea_5661 (31.3.2009).

29. Folkehelseinstituttet. Reseptregistret. www.reseptregistret.no (31.3.2009)

30. Wagner PR. Advances in vaccination against tickborne encephalitis. Expert Rev Vaccines 2008; 7 589-96.

Manuskriptet ble mottatt 22.1. 2009 og godkjent 16.4. 2009. Medisinsk redaktør Åslaug Helland. 